\title{
THE HUMAN SCIENCES AND MORAL JUDGMENT
}

\author{
Jure Zovko (Zagreb/Zadar)
}

\begin{abstract}
ÖZET
Bu makalenin başlıca amacı, "kültürel dönüş", yani Batı ya da Avrupa kültürü gibi, tek bir evrenselin egemenlik düşüncesinden ayrılış ve kaynaklara ilişkin daha geniş bir spektrumdan elde edilen orijinal katkıların Avrupa kültürü ve geleneği içerisinde keşfi, soyut ve teksesli kültürel globalizmin savunmasına indirgenemeyeceğinden, belirli kültürel mirasların süregelen mevcudiyetinin genişleyen karşılıklı anlayış süreci ve yargının felsefi biçimlenişine katkı sağlayan kültürel çeşitliliğin takdiriyle birlikte ortak bir yorumlama süreci, karşılaştırmalı analiz ve eleştirel değerlendirme aracılığıyla - tümü insan bilimlerinin görevleri ve ufkunu oluşturan yanlardır - sürekli yenilenmeye ihtiyaç duyduğunu göstermektir.

Humaniora, modern insanı, onu soyut, izole edilmiş, ve tarihsiz bir şekilde sosyal açıdan içerisinde yer aldığı toplumda sosyal haklardan yoksun olarak kavramsallaştıran yerinden edilmiş birey olarak ele almamalıdır. Ancak bunun yerine varolan devletler ve sosyal kurumlar içerisinde insan bilimleri, kendilerini Aydınlanmanın mirasçıları olarak görenlerin medenilik seviyesini geliştirmenin peşinde olmalılardır. Temel soru, pleonexia'nın ahlaksal olmayan üzümlerinden refah içerisindeki devletin ahlak şarabının nasıl sıkılacağıdır ve bu insan bilimlerinin en özsel sorularından biri olmaya devam eder.
\end{abstract}

Anahtar Kelimeler: İnsan Bilimleri, Hermeneutik, Yaşam Dünyası, Fenomenolojik Refleksiyon, Eylem.

\begin{abstract}
The primary intention of the paper is to show that, in order that the "cultural turn", i.e. the departure from the idea of dominance of a single univeral, Western or European culture, and discovery within the culture and tradition of Europe of original contributions from an ever-wider spectrum of sources, might not be reduced to an apology for abstract and unisono cultural globalism, the living presence of specific cultural heritages needs to be continually renewed through a shared process of interpretation, comparative analysis, critical evaluation - all tasks of the humanities and constituent aspects of the horizon-broadening process of mutual understanding and appreciation of cultural diversity which contribute to the philosophical cultivation of judgment.

The humaniora should not discuss the modern human being as an uprooted individual conceptualizing him as an abstract, isolated, and socially deprived subject in a society without history but they should rather aspire towards improving, within the existing states and social institutions, the level of civility for all who consider themselves heirs to the Enlightenment. The more basic question how to press the moral wine of the welfare state from the immoral grapes of pleonexia is and remains one of the most essential questions of the humaniora.
\end{abstract}

Keywords: Humanities, Hermeneutic, Lebenswelt, Phenomenological Reflection, Praxis. 
The specific character of the humanities is made manifest in the fact that their object of investigation, as Hans-Georg Gadamer pointed out, is not anything abstract or metaphysical, but primarily a manifestation and articulation of the particular social, cultural and historical circumstances in which humanity finds itself at any given moment. The object of study in the humanities is thus that to which we belong: the humanist tradition, which is made evident in a variety of differences and in a pluralism of life forms and world views. In this respect Gadamer maintains: "What makes the human sciences into sciences can be understood more easily from the tradition of the concept of Bildung than from the modern idea of scientific method. It is to the humanistic tradition that we must turn, It is resistance to the claims of modern science it gains a new significance". ${ }^{1}$ The primarily task of the humaniora in the age of globalisation is promote a pluralism of differences with regard to appartenance to various cultures and forms of life, with the added aim of helping to preserve and develop those cultures and life forms. This pluralism of differences does not imply that the prevailing tendency toward rationalising uniformity is to be replaced by cultural and moral relativism. The intention of this paper is emphasize the relevance of experience of a hermeneutic and phenomenolgical reflection in the examination of the world we live in (Lebenswelt). The concept of world as it is elaborated in hermeneutic philosophy, i.e. as a result of the reduction of the categorial view of the world to the "living world" and the resulting explication of the historical and cultural context of living beings, gains thereby a strong culturological aspect. In keeping with the fundamental hermeneutic understanding, to philosophize means to be in the world, to gain understanding by the use of language, to integrate the context of one's own self-conception with the self-conception of the object of our interpretation and so to establish an intersubjective world. Bildung as formation implies according to Gadamer an openness to other points of view or perspectives: "That is what, following Hegel, we emphasizes as the general characteristic of Bildung: keeping oneself open to what is other - to other, more universal points of view. It embraces a sense of proportion and distance in relation to itself, and hence consists in rising above itself to universality" ${ }^{2}$ Gadamer endeavors to emphasize the humanistic dimension of the humanities (Geisteswissenschaften) and to comprehend them as "the true advocates

Hans-Georg Gadamer, Truth and Mathod [TM] Trans. J. Weinsheimer and D. G. Marshall Second Revised Edition, New York: Crossroad Publishing 1989, 18. Plato's thematisation of concern and cultivation of the soul (epimeleia psyches) as presented in the early dialogues, and which attains in Plato's later philosophy a special aura of sanctity and nobility, has had an extensive Wirkungsgeschichte and reception. Care of one's soul, as one of the central topoi in Western European metaphysics, is transformed in Kant's philosophy into the philosophical care for the cultivation of one's own identity, or rather the collective identity of humanity as a whole, and becomes in the descriptive psychology of Wilhelm Dilthey the basis for the justification of the specific task of the humanities (Geisteswissenschaften).

2 Gadamer, TM, 17. 
or emissaries of humanism" ("als die wahren Sachwalter des Humanismus"). ${ }^{3}$ On the first page of Truth and Method Gadamer pleads for the specific character of humanities and distinguishes their investigation from the methodology of the natural sciences: "Its purpose is to seek out those experiences of truth, wherever they may be encountered, which transcend the area of control of the scientific method and to question them concerning their own legitimacy. So the humanities are brought together with other ways of experiencing which lie outside science; with the experience of philosophy, with the experience of art and with the experience of histoy itself." 4

Many critics of contemporary hermeneutical philosophy claim that the hermeneutical request for sense-discernment is indeterminate and vaguely formulated. This, to a degree, also applies to their relativistic notion of truth as advocated by Heidegger, Gadamer and postmodernists who explain the structure and essence of truth through the concept of "play“. We all, seeking to learn and realise something, climb up the language games to the understanding of the world: "In understanding we are drawn into an event of truth and arrive, as it were, too late, if we want to know what we ought to believe.".5

Hermeneutical practice of understanding, through which one needs to arrive at the truths that have to be prevented from falling under the rule of the modern notion of science, actually expresses our belonging to what we understand. Since such hermeneutical reflection dispenses with the assumptions that precede entire scientific methodology, its relevance to a reliable textual interpretation and understanding remains extremely questionable. The greatest danger to interpretation in contemporary human and social sciences is hermeneutical and epistemic relativism, for without normative standards of interpretation no interpretation has any advantage over any other and no explanation is possible at all, a condition which is ultimately insupportable to us human beings because of our natural desire and need to know and understand. American physicist Alan Sokal characterized the tendency of mainstream of postmodern Philosophy in his parodist Essay „Transgressing the Boundaries: Towards a Transformative Hermeneutics of Quantum Gravity“:”, The content

3 Ibid, 9.

4 Ibid. xxii. Dilthey's Distinction between "Explanation" and "Understanding" has contributed to the radical bias that all human experience divides naturally into two parts: 1 . the explanation of the natural world, in which "objective necessity" rules, and 2. Understanding in which the inner experience of life dominates. For Dilthey the notion of "Explanation" is derived from the methodology of the natural sciences and has in this respect its primary application in this field. Wilhelm Windelband, following Dilthey, attempted to draw a clear distinction between the nomothetic goals of the natural sciences (generalizations, abstraction, and universal statements) and the ideographic goals of the human and historical sciences (particular instances, concrete individuals, detailed understanding of the particular). Cf. W. Dilthey, Gesammelte Schriften Die geistige Welt: Einleitung in die Philosophie des Lebens. Erste Hälfte: Abhandlungen zur Grundlegung der Geisteswissenschaften, G. Misch (ed.) Stuttgart: Teubner 1924 vol. 5, p.144 sq..

5 Gadamer, TM. 446. 
and methodology of postmodern science thus provide powerful intellectual support for the progressive political project, understood in its broadest sense: the transgressing of boundaries, the breaking down of barriers, the radical democratization of all aspects of social, economic, political and cultural life." 6

The question whether it is possible to establish in the area of ethics a normative universalism that would give us some orientation for distinguishing the morally right from the wrong and the good from the bad in our praxis will in no way become superfluous in the modern life-world (Lebenswelt) even when our modern democracies are functioning. Without a doubt, human beings who are living in modern democratic societies are intensely discussing basic ethical problems such as the relation of individual freedom and political justice, the universal validity of human rights, global ecological responsibility for endangering and destroying our biological environment, and looking for resolutions without appealing to religious authority. The question as to the justification for our ethical actions gives us an opportunity to analyze presupposed and recognized ethical norms and assess their relevance for our modern democratic society at length. The question as to whether it is possible to make concrete decisions correctly based on general norms has been raised time and again; it is indeed possible to answer it by rationally reasoning on the normative principles that guide our action and acutely analyzing concrete praxis.

Some hermeneutic philosophers who take up the traditional philosophia practica in their argumentation have tried to make the Kantian formalistic "ethics of laws" based on the general principle that duty is unconditional more accessible (to his critics) by supplementing it with the position of Aristotelian ethics that reflects on the concrete application of ethical knowledge (sittliche Wissen). ${ }^{7}$ The Kantian path remained dissatisfying to Hans-Georg Gadamer because one cannot make a sovereign decision on the question what is the right action in the given situation due to the formalistic and reflective overgeneralization of Kantian ethics. Gadamer held that Kantian rigorist moralism does not help us when confronted with different moral demands. The consistency test of maxims alone will not facilitate our making a responsible ethical decision in praxis.

Gadamer shows that Kant's moral-philosophical reflections refer to "ethical principles" only in borderline or exceptional situations when there is a contrast of duty and affinity and thus turn such situations into "a case for conscience testing" ${ }^{8}$ where-

$6 \quad$ Cf. Social Text 46/47 (1996) 217-252; p. 229.

7 Cf. Hans-Georg Gadamer, "Über die Möglichkeit einer philosophischen Ethik", Gesammelte Werke vol. 4, Tübingen 1987, 177. Cf. John McDowell, Mind and World, London: Harvard University Press 1994, p. 84: „If we generalize the way Aristotle conceives the moulding of ethical character, we arrive at the notion of having one's eyes opened to reasons at large by acquiring a second nature. I cannot think of good short English expression for this, but it is what figures in German philosophy as Bildung."

8 Gadamer, GW, 4, 180. 
by the aspect of the moral decision and its relevance for the character formation of the agent come to the fore. The vigilance of conscience, which makes itself noticeable only in exceptional cases of conflict, is unfortunately, according to Gadamer, no permanent habitus but it primarily depends on the "substantiality of the ethical order" into which we are always already integrated. That is why Gadamer think that it is appropriate to take the Aristotelian path in ethics. His moral philosophy bethinks the connection between logos and ethos or "between the subjectivity of knowledge and the substantiality of being" and analyzes how to put into effect general virtues and apply them in the given situation concretely. ${ }^{9}$ On a similar path, J. McDowell pleads for a successful synthesis of nature and ethics as articulated by the Aristotelian philosophy of the "second nature". This represents a feasible alternative to the currently predominant scientistic concept of the world and nature. He writes that "our nature is largely second nature, and our second nature is the way it is not just because of the potentialities we were born with, but also because of our upbringing, our Bildung. Given the notion of second nature, we can say that the way our lives are shaped by reason is natural, even while we deny that the structure of the space of reasons can be integrated into the layout of the realm of law. This is the partial re-enchantment of nature that I spoke of." ${ }^{10}$ Wittgenstein's later work contains several essential philosophical concepts, such as "forms of life" (Lebensformen), "world picture" (Weltbild), "system of relationships" (Bezugssystem), but also "manner of thinking" (Denkstil), concepts which contain reference to various aspects of human identity and cultural productivity. Taking into account the implications they involve, these concepts offer a wide variety of possibities for achieving as objective a knowledge and understanding of the "other" as possible, taken in the broadest sense from an understanding of nature and the natural world to an understanding of other peoples and cultures, whatever the form of communication.

By updating Aristotle's practical philosophy, Gadamer consciously distances himself from the two most influential ethical currents in the tradition of Continental European philosophy, i.e., on the one hand, Kant's "deontological" ethics, and, on the other hand, the "material ethics of values" established by Max Scheler and Nicolai Hartmann. Kant's deontological concept of normative standardization does not make an exception for ethical demands and N. Hartmann holds the view that ethics is indeed able to teach "what is ethically right, as geometry is able to teach what is geometrically true." ${ }^{11}$ By realizing values, human beings are included in an interconnection that transcends them.

The shortcoming of normative utilitarian theory is best visible in the readiness to put into question all norms that they do not maximize benefits. Using the norm of justice in particular, critics of utilitarianism have convincingly argued that we must

9 Ibid. 183.

10 J. McDowell (1994). Ibid. 87 sq.

11 N. Hartmann, Ethik, Berlin: W. de Gruyter,1926, 27. 
not violate justice in case of conflict with the principle of benefit. They have made plausible that it is not possible to integrate principles of justice into utilitarian ethics without going beyond its scope. An ethics, which, from the point of view adopted by the homo oeconomicus, interprets the freedom to act as the pursuit of benefit and profit maximization is not fair to those who are handicapped or uncompetitive. Free business competition is of course not guided by the Kantian categorical imperative but rather by the principle of pleonexia, which, as is generally known, has been considered as the structural negation of individual and social justice since Plato. Pleonexia, defined as the want for more possession, is the basic determinant of free market economy because every business activity complies with the (principles) of benefit and profit maximization. In praxis, the care for realizing one's own profits always obtains priority over one's responsibility for the welfare of others. Without exception, thinkers who equate the free accumulation of capital with the inviolable right of every person to individual and political liberty advocate a model for the minimal state in which it remains impermissible to limit personal liberty by disposing of private property without approval from its citizens. ${ }^{12}$ That is why the representatives of classical liberalism advocate the ideals of efficiency and the unregulated markets which are supposedly congruent with the political ideal of liberty. Robert Nozick, one of the most prominent representatives of radical neoliberalism in modern times, or more precisely, libertarianism, believed that market mechanisms alone may regulate and equalize divergent egotistical interests. He rejected all kinds of redistribution and social transfer a limine: "...there is no moral outweighing on one of our lives by others so as to lead to a greater overall social good. There is no justified sacrifice of some of us for others". ${ }^{13}$ Every kind of reallocation in the name of social justice is at the same time, according to Nozick, simply a violation of the law because it ipso facto violates personal liberty and the individual right to private property.

We could take recourse to the Kantian criticism of egotism as a counterargument to this coupling of personal liberty and private property in Nozick's supposedly quintessential theory of human rights, which is and remains regardless to all persons in need of help. In his posthumously published notes "Reflections on Anthropology", Kant compares the egotist to "Cyclops" who "is in need of another eye" to be able to see things and events "from the viewpoint of other human beings". ${ }^{14}$

12 In connection to this, Robert Nozick and J. M. Buchenen are paradigmatic. Cf. R. Nozick, Anarchy, State and Utopia, New York: Basic Book 1974; F. A. v. Hayek, Law, Legislation and Liberty- A New Statement of the Liberal Principles of Justice and Political Economy. Vol. 2. Mirage of Social Justice. London 1976. J. M. Buchanan, The Limits of Liberty: Between Anarchy and Leviathan. Chicago 1975.

13 Robert Nozick (1974), 33.

14 I. Kant, Akademieausgabe, Berlin 1900 sq., vol. 15, 395. 
The question of implementing ethics into market economy determined by autonomy and instrumental reason is and remains a precarious issue. In their critical writings, Karl Marx and Friedrich Engels already remarked that liberal market society is and remains closely coupled with the utilitarian weltanschauung. In German Ideology, the two critics of capitalism criticize utilitarianism for exploiting the human being through the human being (eine „exploitation de l'homme par l'homme“). ${ }^{15}$

The humaniora should not discuss the modern human being as an uprooted individual conceptualizing him as an abstract, isolated, and socially deprived subject in a society without history but they should rather aspire towards improving, within the existing states and social institutions, the level of civility for all who consider themselves heirs to the Enlightenment. The more basic question how to press the moral wine of the welfare state from the immoral grapes of pleonexia is and remains one of the most essential questions of the humaniora.

The essential affinity in structure between hermeneutic philosophy and Aristotelian ethics lies in the shared conviction that we understand ourselves in executing our thoughts and actions as always already situated and embedded in an existing ethical life-world, family, society, and state. Our hermeneutic and practical reflections take place against the backdrop of this existing ethical life-world. The education towards reasonability turns out to be the precondition for applying concepts of obligatory norms for human conduct and normative concepts for rational political constitution. This is why Hegel admired Aristotle for his conception of the polis. ${ }^{16}$ The complex praxis of moral understanding is the process of reflexively applying ethical norms adopted through education to concrete situations of human life or as conscious conduct through which a life-form establishes itself and those who acquire moral understanding articulate their belonging to that which they understand.

According to Aristotle, the goal of practical philosophy is not knowledge as such but human action and its success. ${ }^{17}$ But since all human individuals are equally determined by the structures of the existing moral life-world and their contingencies, they must take into consideration the possibility of missing their targets. Every ethical theory must accept that no agent is master over all the consequences of his action. According to Gadamer, Aristotle distinguished himself as the most successful founder of philosophical ethics because he realized that ethical knowledge, phronesis, does not exhaust itself in the general concept of ethical virtues but proves itself worth in specific concrete situations: "Ethical knowledge recognizes what is right (tunlich),

15 Karl Marx/Friedrich Engels, Werke, Berlin 1956, vol. 3, 394. Ernst Tugendhat adopts the view that utilitarianism is "the ideology of capitalism“, „for it permits morally justifying economic growth as such without regards for questions of allocation". Cf. Tugendhat, Vorlesungen über Ethik. Frankfurt: Suhrkamp 1993, 327.

16 Cf.. Aristotle, Ethica Nicomachea 1095 a 3 ff.

17 Cf. ibid. 1095 a5: To telos estin ou gnosis alla praxis. 
what a situation requires, and it recognizes this based on reasoning by putting the concrete situation into a relation to what one deems right and correct in general." ${ }^{18}$ The primary substantiality of right and custom (Sitte) adopted by education is the indispensable condition for an individual's ethical being. It is the guide for the decision of the agent and it conditions his decision on what is right. The object of ethical knowledge, phronesis, includes neither changeless and eternal being nor the highest and constant principles but it exclusively addresses contingent circumstances or "that which may be thus or otherwise" (to endechomenon allos echein). Except for circumstances in which exceptions are always possible, this refers primarily to human actions that are always singular, unrepeatable, and irrevocable. It is, therefore, reasonable not to pursue perfect exactness and accuracy in the world of action but rather prudent consideration and duly analysis of the state of affairs in their interconnection. Since the identity of the human person established itself through executed and omitted actions in time, all individuals are obliged to consider the consequences of their actions.

Aristotle tried taking a skeptical step beyond Socratic-Platonic ethical intellectualism indicating that the good is the primary object of practical philosophy. We encounter it in human praxis and it informs our human lifestyle. For human beings do not exist abstractly but they grow up in a family, live in a specific polis, and are molded by their social and ethical environment. That is why it is useless to consider abstract ethical norms. Aristotle demands that we realize virtue according to ethical knowledge, phronesis, instead of theorizing focused on the good and right in general. The general becomes determinate through concretization. Although Aristotle, as Plato, considered the virtues to be indispensable preconditions for eudaimonia, there is no certain warranty of success but only reasoned signposting. For teleological reasons, the human being is obliged to act in accordance with his reasonable insights. According to Aristotle, only those who pursue a serious goal (skopos) and are at the same time capable of judging the concrete situation in light of what is expected of them in general deserve the attribute phronimos. Similar to the archer who must look at his target to hit it, the agent must contemplate the good life as the scope of ethical reflection and the goal of his or her meaning and (self-)fulfillment. ${ }^{19}$

The main trajectory of the teleological mode of argumentation is that Aristotle confers the interconnections existing in nature to the determinate purpose of human existence. He excludes meaningless existence a limine. His critics recognized a logical error in his mode of argumentation and conclusion by analogy: by virtue of the fact that all human actions aim at a goal, he concludes that there must be a highest goal of all human actions. However, it does not follow from the view that there is a goal in human life that human life as such is embedded in a teleological order, i.e., that it

18 Gadamer (1987), 183.

19 EN. 1094 a 23 
has purpose in cosmic terms. ${ }^{20}$ At the very least, we may rightly state that we are Aristotelians to a high degree in our ethical life-world. Regarding the Aristotelian constitution of our existence, J. Nida-Rümelin writes: „Ethical theory cannot distance itself too much from the experience of the life-world, the endowment of meaning to our life, and the praxis of everyday interaction, if it wants to be taken seriously." ${ }^{21}$

By raising his ethical questions, Aristotle tries to deepen the main topic of the Socratic dialogues; that is, how to realize the good life and how ethical reflection may serve human education. The authentic intention of the Socratic investigations, as per the early Platonic dialogues, is to emphasize clearly the ethical norm as a paradigm and with an eye to this paradigm enable us to decide whether a specific action is morally permissible or impermissible. The Socratic irony of non-knowledge does not transfer an ethical doctrine of general validity via negationis but it rather presents us with a paradigm for ethical self-examination and self-recognition by referring us to the experience of thought and existence, an experience that is built up in dialogue and able to take effect in dialogue alone. ${ }^{22}$ Following Aristotle's moral philosophy and pragmatic attitude, it is possible to elaborate a philosophy oriented towards ethics in the sense of the philosophia practica whose main task is rethinking the communicative character of our praxis and life-form. Gadamer's engagement with practical philosophy was decisively inspired by Martin Heidegger's Marburg lectures on the Platonic dialogue Sophistes from 1924/5, where Heidegger deals with the sixth book of the Nicomachean ethics at length. The fact that Heidegger applies the most important philosophical concept of Aristotelian ethics to the analysis of being-there and existence is understandable because of the structural affinity between the determinations of action and existence. Similar to the agent who does not have the option of refusing to act because of time-pressure, this applies to him who exists; he exists and he must exist and he cannot do otherwise but execute his existence in time making concrete decisions along the way. Here Heidegger illuminates the concept phronesis in a remarkable way; he does not, however, consistently follow Aristotle's ethical reflection but he explicates human action by raising the question as to the meaningful understanding of being. Heidegger defines phronesis as the ability of deliberating (überlegen) well and appropriately. The object of delibaration and consideration (Überlegung) is factual life, "zoe itself", his telos, "the being of the one who is deliberating" his principle the being-there of the human being. ${ }^{23}$ It is not possible to experiment at whim in ethical action because the ethical knowledge of

20 Vgl. Günther Patzig, Ethik ohne Metaphysik. 2., durchgesehene und erweiterte Auflage. Göttingen: Vandenhoeck \& Ruprecht 1983, 41.

21 Julian Nida-Rümelin, Demokratie und Wahrheit. München: Beck 2006, 113.

22 Cf. Gadamer (1987), 210; Cf. G. Vlastos, Socrates. Ironist and Moral Philosopher Ithaca: Cornell University Press, 1991).

23 Martin Heidegger, Gesamtausgabe, vol. 29, Frankfurt: Klostermann 1992, 48. 
phronesis refers to the being of the human being-there and because it analyzes and understands this being in his life-world. In reflecting on phronesis there is, according to Heidegger, either "the sincerity of the resolute decision“" or "Self-failing” Self-failure?. ${ }^{24}$ Since phronesis relates to the being of the human being who is by nature a contingent being, an endechomenon allos echon, it is "new every time", since it must "uncover the concrete singular possibilities of the being of being-there (Daseins)". ${ }^{25}$ According to Heidegger's judgment phronesis is paradoxically the "highest mode of cognition of the human being" because its intended object, the being-there of the human being in its temporality deserves "the most sincerity" ${ }^{26}$

In contrast to Heidegger's transformation of phronesis, which he defines in Being and Time as the call of conscience addressed to the being-there, in which responsibility for one's own self is evoked, Gadamer defines phronesis as "reasonability" which guides our praxis and life-form. Praxis, as a key-concept in Gadamer's late philosophy, denotes "self-conduct and action in solidarity", whereby solidarity is the "decisive condition for all societal rationality". ${ }^{27}$ Practical philosophy always starts with the concrete situation in which we find ourselves and then asks "what is reasonable there, what is to be done in the sense of what is right" ${ }^{28}$ We ourselves must determine what is to be done by consulting others and entering into an exchange of experience with each other. We cannot control our praxis by means of schematic instructions; praxis always implies the choice of different possibilities and we must make our decision instantly most of the time. Gadamer holds that this process of communication (Verständigung) is not a matter of monologues but that we must enter into it through dialogues. If we must make each other understand our very own situation, then we have already entered into the process of hermeneutic reflection: we must interpret the situation through its integrative interconnection (between us). Communication what is to be done, as accomplished through interpretation, is reasonable self-responsibility because as political citizens we make decisions that we are able to advocate. According to Gadamer, social praxis as our authentic form of life consists in "determining common purposes through common and thoughtful choice and concretizing them through practical reflections on what is to be done in our given situation. That is societal reason." ${ }^{29}$ Since the practical instruction of reflection always articulates a relation to the "being of the human being" 30 and chooses the bumanum manifesting in cultural creations as its object of reflection, Gadamer holds

\footnotetext{
Ibid. 54.

Ibid. 139.

Ibid. 135 .

Gadamer (1987), 228.

Gadamer (1993), 67

Ibid. 72.

Gadamer (1987), 245.
} 
that the commitments of praxis and hence the efficacy of societal reason in praxis are always much greater than theorists believe. ${ }^{31} \mathrm{~A}$ strict scientification of the praxis of understanding is not possible for Gadamer because the praxis of understanding articulates the self-conduct of the human being (in relation) to itself and (in relation to) what he knows of himself. The societal praxis is, according to Gadamer, not an innovation, for a form of science is running through the intellectual history of the Occident, the so-called scientia practica, which transports cognitions of human conduct and life-praxis and raises the question how to integrate knowledge into the practical consciousness of those who act. Even though, from the point of view adopted by the modern philosophy of language, it is demonstrable that there is a multitude of established games of justification that are grounded in our life-world and that determine our ethical life-form and its praxis of mutual understanding.

Gadamer demonstrates to what degree the problem of application is particularly topical even in the highly developed sciences by given medicine as an example. False diagnosis and false subsumptions arise in medicine not because of failures of science but as a general rule at the expense of the physician's power of judgment. The physician's expertise obviously does not depend on his training through purely scientific research alone but also on his ability to apply his general knowledge to the concrete life-situation. In any case, it is not possible to set aside the question of humaneness in the art of healing because it is primarily about life itself which is entrusted to the physician's ability. It is remarkable that Aristotle, appealing to Plato, compares the physician's occupation with rhetoric; the physician should be able "to see the whole of nature" similar to the true master of the art of speech. "Beside the 'case' that he is treating, he must also look at the human being as a whole in his life-situation. He must even reflect on his own action and how he affects the patient. "32 Gadamer illustrates the alienating transformation of the medical profession in modern society by exemplifying the renowned difference between the medical praxis of a family doctor who on account of his cautious assignment usually was a family friend and the clinical physician who visits his patients only during their hospitalization and treats them as ill persons with professional distance. The physician's power of persuasion together with the patient's trust and cooperation increase the healing effects, ${ }^{33}$ which by no means can be determined as scientific progress or denied in praxis. Gadamer characterizes the professional occupation of the clinical physician, which has proven to be abstract, as the prototype of modern expert science that excludes the hermeneutic reflection of the concrete. Nowadays, we are living in an expert society that is at the same time a society of functionaries that attunes experts entirely to administering their function, while they see their opportunities for advancement exclusively in do-

$31 \quad$ Ibid. 225

32 Gadamer, Über die Verborgenheit der Gesundheit. Frankfurt: Suhrkamp 1993, 63

33 Gadamer (1987), 258. 
ing so. What is worrisome in such a society is that ever fewer people make thoughtful and responsible decisions and ever more just serve the apparatus as experts in the field. This results in the degeneration of praxis into technique or "the regress into societal unreason". ${ }^{34}$ Thoroughly rethinking the ethical and societal praxis against the model of humanity remains the primary task of practical philosophy.

Whether practical philosophy is able to perform almost everything that it undertakes because of its universal claim to understanding life praxis and ethical experience of the world remains a matter of concern. In my opinion, the idea of reason as a guide for praxis, which does not take recourse to generally valid norms, is justifiable only as integral and provisory morality, which recognizes and respects institutional conventions and ethical customs as basic prima facie rules. A concept of ethics that dispenses with justifying moral norms of conduct for the current situation always anew is unable to come to terms with the problems posed by the current world of technology. In discussing the dangers of ecological catastrophes or genetic engineering or explicating the universal character of justice regarding the respect for the inviolable dignity of the human being and the burning question of securing rudimental livelihood and world sustenance, we must unconditionally take recourse to universal ethical norms. The basic principle of Gadamer's practical philosophy according to which existing moral norms cannot relieve the individual from responsible decision-making, should not be misunderstood as a sufficient argument against the point that universal ethical norms require objective justification and acceptance. Critical philosophy in the area of ethics should reflect on the rational principles of decision-making and conduct in order to enable us to cultivate and strengthen our power of judgment and to penetrate the concrete situation clearer and more completely. The fact that it is not possible to apply generally valid norms to concrete state of affairs without limitation does not justify anybody in discounting universal norms of action and concepts of normative standardization as obsolete. The meaning of moral norms is primarily, as Günther Patzig puts it, „to secure the conditions of possibility for an endurable or even enjoyable cohabitation of human beings." ${ }^{35}$ These are norms of human cohabitation that largely underlie our everyday praxis, that are rationally justifiable, generally acceptable, and verifiable through experience in most cases. ${ }^{36}$ As critically reviewed and rationally justified norms, they are an integral part of our ethical life-world.

The modern democratic societies tend to promote pluralistic relativism regarding the justification of norms, while the right to a different opinion is elevated to the highest and inviolable value. The fact that pluralistic relativists present ever more arguments against the possibility of giving rational and generally valid justifications

$34 \quad$ Ibid. 219.

35 Patzig, 135.

36 Vgl. Patzig, 134. 
for moral norms does not prevent us from refuting their power of persuasion by means of rational discourse. Among other reasons, the argumentation put forth by ethical relativists is unsustainable, because pluralistic relativism with respect to values is negated by a legal positivism in which "ethically unbinding law loses its obligatory character." 37 On the other hand, every theoretician of legal positivism should know that the norms of positive law, as W. Wieland puts it, "are in need of appraisal", which is executable "only by an accomplished power of judgment" ${ }^{38}$ Without a doubt, there are ethical norms that are made relative under any circumstances and that should consistently determine our political and social action. Such norms that anyone cannot deny and that are not, to put it in Kantian terms, replaceable by any other equivalent, include human rights, the indefeasibility of human dignity, personal liberty, the right to life, just and equal opportunity for all citizens, and the moral obligation to take global responsibility for the protection of the environment.

Human action in average everyday life usually takes place in the area of institutional and provisory morality. It takes recourse to regulative norms mostly in limit situations and at times of crisis. ${ }^{39}$ Human life is more often than we can think ahead a life of subsequent situations of crises in which human dignity and personal integrity are in danger and a state of potentially irreversible damage of the natural living conditions for human beings is conceivable. In such cases, we can stabilize our lives only by justifying deontological norms. The rapid development of scientific research and technological world domination has unfortunately lead our society into such a limit situation in which the human being cannot come to terms with difficult problems of the current world without taking recourse to basic ethical norms. The human being of today is living under the threat of an ecological world catastrophe that could result in the inhabitability of earth and the extinction of humanity. We are still far away from overseeing all of the possible and shocking consequences of genetic engineering and cloning living beings including human beings. The accountability for human action under the conditions of the modern scientific and technological development in the digital society by no means dispenses with normative ethical justification. Without these basic ethical norms, the human being would entirely lose orientation in modern society and have no starting point for cultivating his ethical attitude and faculty of judgment.

The question of normative values and individual rights that are not relative- a question that has been raised in ethical discussions time and again-indicate that deontological argumentation is indispensable for normatively justifying and distinguishing the morally right from the wrong. Wolfgang Wieland has mostly analyzed

37 J. Nida-Rümelin, Demokratie und Wahrheit, S. 21.

38 Wolfgang Wieland, „Kants Rechtsphilosophie der Urteilskraft“, in: Zeitschrift für philosophische Forschung 52 (1998) 1-22; p. 19.

39 Cf. Wolfgang Wieland, Verantwortung - Prinzip der Ethik?. Heidelberg: Winter 1999, 99. 
areas of our life-world in which consequentialist concepts of ethics are insufficient. "A good example for values that cannot be accounted for in any balance and must not be made relative to any purpose or benefit are human rights. Particularly, human rights must not be put up for discussion or made relative, not even in exceptional cases, not even for the benefit of expected advantages no matter how great they may be. That is the meaning of the indefeasibility and inviolability that we use to ascribe to these rights. According to the idea of these rights, no one of his own kind has bestowed them upon the human being and no one can deprive him of them. They would cease to be human rights, if it were possible to account for their benefit in any kind of assessment of consequences of an action. " ${ }^{40}$ In spite of all advantages that the thesis of teleological norms give us over other kinds of ethical justifications of norms, we depend on the prudent and practical power of judgment in our life praxis in concretely applying norms or assessing violations of norms.

The faculty of moral judgment is an integral part of both ethical theory and the application of prudential reasoning. The moral power of judgment is required for answering the question of the right conduct in our own lives and it includes more complex questions of the value of life and how to live our lives. As reflective power of judgment, it should be a cultivated faculty by means of which we should act in an appropriate way in a concrete case, especially where there are prima facie conflicts between several different moral norms and institutional views. In that sense, Kant already spoke of "healthy reason" (gesunde Vernunft). ${ }^{41}$

$40 \quad$ Wolfgang Wieland, (1999), 92.

${ }^{41}$ Kant, Akademie-Ausgabe, V, 169. 